Article

\title{
Investigation of the Anti-Methicillin-Resistant Staphylococcus aureus Activity of (+)-Tanikolide- and (+)-Malyngolide-Based Analogues Prepared by Asymmetric Synthesis
}

\author{
Joseph Breheny ${ }^{1}$, Cian Kingston ${ }^{2}$, Robert Doran ${ }^{1}$, Joao Anes ${ }^{3}$, Marta Martins ${ }^{3}$, Séamus Fanning ${ }^{3}$ (D) \\ and Patrick J. Guiry ${ }^{1,2, *}$ \\ 1 Centre for Synthesis and Chemical Biology, School of Chemistry, University College Dublin, Belfield, \\ Dublin D04 N2E5, Ireland; joseph.breheny@ucdconnect.ie (J.B.); robert.doran@ucdconnect.ie (R.D.) \\ 2 Synthesis and Solid State Pharmaceutical Centre, School of Chemistry, University College Dublin, Belfield, \\ Dublin D04 N2E5, Ireland; cian.kingston@ucdconnect.ie \\ 3 UCD-Centre for Food Safety, University College Dublin, Belfield, Dublin D04 N2E5, Ireland; \\ joao.anes@ucdconnect.ie (J.A.); marta.martins@ucd.ie (M.M.); sfanning@ucd.ie (S.F.) \\ * Correspondence: p.guiry@ucd.ie; Tel.: +353-1-716-2309
}

check for updates

Citation: Breheny, J.; Kingston, C.; Doran, R.; Anes, J.; Martins, M.;

Fanning, S.; Guiry, P.J. Investigation of the Anti-Methicillin-Resistant Staphylococcus aureus Activity of

(+)-Tanikolide- and

(+)-Malyngolide-Based Analogues Prepared by Asymmetric Synthesis. Int. J. Mol. Sci. 2021, 22, 6400.

https://doi.org/10.3390/ijms22126400

Academic Editor: Witold Gładkowski

Received: 10 March 2021

Accepted: 10 June 2021

Published: 15 June 2021

Publisher's Note: MDPI stays neutral with regard to jurisdictional claims in published maps and institutional affiliations.

Copyright: (c) 2021 by the authors. Licensee MDPI, Basel, Switzerland. This article is an open access article distributed under the terms and conditions of the Creative Commons Attribution (CC BY) license (https:// creativecommons.org/licenses/by/ $4.0 /)$.

\begin{abstract}
Herein, we report antibacterial and antifungal evaluation of a series of previously prepared (+)-tanikolide analogues. One analogue, $(4 S, 6 S)-4$-methyltanikolide, displayed promising anti-methicillin-resistant Staphylococcus aureus activity with a MIC of $12.5 \mu \mathrm{g} / \mathrm{mL}$. Based on the antimicrobial properties of the structurally related (-)-malyngolide, two further analogues (4S,6S)-4methylmalyngolide and $(4 R, 6 S)$-4-methylmalyngolide bearing a shortened $n$-nonyl alkyl side chain were prepared in the present study using a $\mathrm{ZrCl}_{4}$-catalysed deprotection/cyclisation as the key step in their asymmetric synthesis. When these were tested for activity against anti-methicillin-resistant Staphylococcus aureus, the MIC increased to $50 \mu \mathrm{g} / \mathrm{mL}$.
\end{abstract}

Keywords: (+)-tanikolide; (-)-malyngolide; asymmetric synthesis; anti-methicillin-resistant Staphylococcus aureus activity

\section{Introduction}

We developed a $\mathrm{ZrCl}_{4}$-catalysed one-pot deprotection/cyclisation synthetic protocol for the construction of $\delta$-lactones [1]. The methodology was subsequently applied in the asymmetric synthesis of both enantiomers of a mosquito attractant pheromone [2], substituted tetrahydropyrans which provided useful synthons for the enantioselective synthesis of (+)-exo- and (+)-endo-brevicomin [3] and for the efficient synthesis of (-)frontalin and (-)-exo-isobrevicomin [4]. Finally, of relevance to this report, the methodology was applied to the asymmetric synthesis of (+)-tanikolide, 1, affording the $\delta$-lactone based natural product in an overall yield of 26.4\% [5]. (+)-Tanikolide 1 displays strong toxicity against brine shrimp and snails and interesting antifungal activity against C. albicans [6]. C. albicans is the most common fungal pathogen of human diseases and together with other Candida species are responsible for ca. 400,000 life-threatening infections per annum with a mortality rate as high as 40\% [7,8]. Current therapeutic drugs for Candida infections include members of five classes of compounds: polyenes, allylamines, azoles, fluoropyrimidines and echinocandins [9] with amphotericin B, terbinafine, fluconazole, 5-fluorocytosine and caspofungin being the most well-known examples [10].

$(+)$-Tanikolide $\mathbf{1}$ is structurally closely related to the marine antibiotic (-)-malyngolide, 2, with three key differences illustrated in Figure 1; a shortened alkyl side chain (Figure 1, 2 difference A), opposite configuration at the quaternary stereocentre (Figure 1, 2 difference B) and a methyl group $\alpha$ - to the carbonyl (Figure 1, 2 difference C). Interestingly, despite the similarity to (+)-tanikolide 1, (-)-malyngolide 2 displays no activity against 
C. albicans [6]. However, (-)-malyngolide 2 does display anti-microbial activity against $M y-$ obacterium smegmatis, Staphylococcus aureus, Bacillus subtilis and Streptococcus pyogenes [11]. The bacterium Staphylococcus aureus is among one of the most aggressive human pathogenic agents [12]. Antibiotic resistance to $S$. aureus is a major medical issue [13] and is the result of the widespread use of antibacterial antibiotics since the 1940s [14]. The most effective antibiotics for MRSA eradication are vancomycin, linezolid and a few others in combination with vancomycin. Daptomycin, clindamycin, doxycycline, tigecyclin and trimethoprimsulfamethoxazole combination is also efficient against most MRSA strains [15]. The search for new compounds to act as antifungal and antimicrobial agents is an active field of research and, herein, we report our results with analogues of (+)-tanikolide $\mathbf{1}$ and (-)malyngolide 2 .<smiles>O=C1CCC[C@@H](CO)O1</smiles>
1

(+)-tanikolide antifungal activity

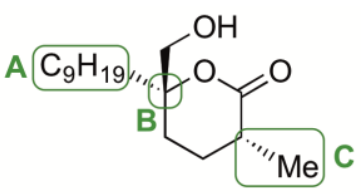

2

(-)-malyngolide antimicrobial activity

Figure 1. (+)-Tanikolide and (-)-malyngolide.

In addition, to our reported synthesis of (+)-tanikolide 1, we wished to probe the biological importance of the position of the methyl group and hence the four $\beta$-methyl modified analogues (3-6) were synthesised using the same $\delta$-lactone forming methodology with the aim to enhance the antifungal activity against $C$. albicans (Figure 2) [5]. These analogues (3-6) were subsequently biologically evaluated, the results of which we report now (Table 1).<smiles>CC1CC(=O)O[C@H](CO)C1</smiles>

3

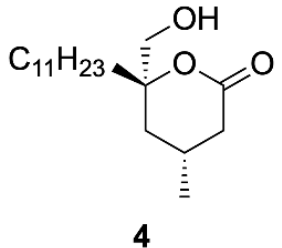

4
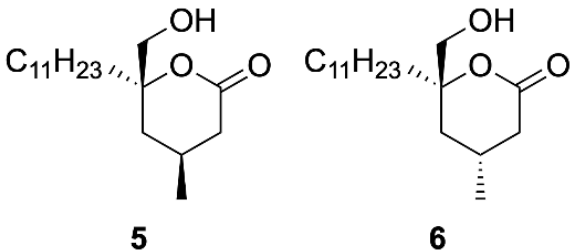

6

Figure 2. $\beta$-Methyl-(+)-tanikolide based analogues 3-6.

Table 1. Antibacterial activity of 3-6-MIC and MBC results (triplicates) ${ }^{[a]}$.

\begin{tabular}{|c|c|c|c|c|c|c|c|c|}
\hline \multirow{2}{*}{ Compound } & \multicolumn{2}{|c|}{ E. coli 25922} & \multicolumn{2}{|c|}{ E. coli 4} & \multicolumn{2}{|c|}{ MRSA ATCC 43300} & \multicolumn{2}{|c|}{ MRSA 06/04 } \\
\hline & $\mathrm{MIC}^{[\mathrm{b}]}$ & MBC & MIC & MBC & MIC & MBC & MIC & MBC \\
\hline 3 & $>100$ & $>100$ & $>100$ & $>100$ & $>100$ & $>100$ & $>100 *$ & $>100$ \\
\hline 4 & $>100$ & $>100$ & $>100$ & $>100$ & $>100$ & $>100$ & $>100 *$ & $>100$ \\
\hline 5 & $>100$ & $>100$ & $>100$ & $>100$ & 12.5 & 12.5 & 12.5 & 50 \\
\hline 6 & $>100$ & $>100$ & $>100$ & $>100$ & $>100$ & $>100$ & $>100 *$ & $>100$ \\
\hline
\end{tabular}

[a] * denotes a change in strain phenotype ${ }^{[b]}$ MIC-minimum inhibitory concentration, MBC-minimum bactericidal concentration. Values are given in $\mu \mathrm{g} / \mathrm{mL}$. Bold-face values denote compounds that showed activity against the tested bacteria. The maximum concentration of compound tested in each case was $100 \mu \mathrm{g} / \mathrm{mL}$.

\section{Results}

The four $\beta$-methyl (+)-tanikolide based analogues (3-6) were submitted for biological testing to ascertain if they exhibited any antifungal and antimicrobial activity. The compounds were tested against Candida albicans and Candida parapsilosis. Unfortunately, the compounds displayed no inhibition of growth even at concentrations as high as $800 \mu \mathrm{g} / \mathrm{mL}$. 
However, the series of compounds were also tested for activity against Gram-positive and Gram-negative bacterial strains, methicillin-resistant Staphylococcus aureus (MRSA) and Escherichia coli (E. coli) (Table 1). Although the compounds showed no activity against E. coli, analogue 5 was found to exhibit promising results against MRSA with an MIC of $12.5 \mu \mathrm{g} / \mathrm{mL}$. This compares favourably with the typical MIC values of vancomycin $(4.8 \mu \mathrm{g} / \mathrm{mL})$ [16] and linezolid (0.1-4 mg/L) [17]. Analogue 5 was shown to be stable for the duration of the assay. The configuration of a methyl group-to the carbonyl had a dramatic effect upon the specific activity of the compound, as shown by analogue 6 which displayed no bioactivity. Analogue 5 bears the opposite stereochemistry at the quaternary carbon centre to 1 , upon which the analogues were initially designed. Interestingly, the configuration is the same as found in (-)-malyngolide 2 , a known anti-microbial agent.

In an effort to further increase the efficacy of these potential anti-MRSA agents, we wished to synthesise analogues bearing the shortened $n$-nonyl side chain found in (-)malyngolide 2 . The optimal stereochemistry of the $\beta$-methyl group will be determined once again by the synthesis and evaluation of both diastereomers. A number of approaches to asymmetric synthesis of $\mathbf{2}$ have been published since the first report by Mukaiyama in 1980 [18], including the use of chiral auxiliary [19-27], chiral pool [28-37], other asymmetric syntheses [38-40] and catalytic asymmetric syntheses [41-49].

The synthesis of (-)-malyngolide based analogues 7 and 8 was adapted from our initial synthesis of (+)-tanikolide based compounds 3-6 (Figure 3) [5]. The first step was monoalkylation of phosphonate $\mathbf{9}$ which afforded intermediate $\mathbf{1 0}$ in a yield of $51 \%$. A Horner-Wadsworth-Emmons reaction with 35\% aqueous formaldehyde successfully gave the desired terminal alkene of intermediate $\mathbf{1 1}$ in a yield of 73\%. DIBAL reduction of the ethyl ester provided allylic alcohol 12 in 25\% yield. A Sharpless asymmetric epoxidation using $\mathrm{Ti}(\mathrm{OiPr})_{4},(-)$-diisopropyltartrate and cumene hydroperoxide was used to afford intermediate 13 with the desired stereochemistry in a yield of $80 \%$. The $e e$ was subsequently determined after benzyl protection of the primary alcohol in $\mathbf{1 3}$ due to the absence of a chromophore on the unprotected epoxide. The stereochemistry of the product was assigned based on extensive NOE experiments carried out on analogues 3-6 [5]. Protection of the cohol was achieved using sodium hydride as a base with benzyl bromide in the presence of tetrabutylammonium iodide to give $\mathbf{1 4}$ in a yield of $86 \%$ with an ee greater than $99 \%$ (see Figure S1 for reference chiral SFC chromatograms). At this point a diol protection/bromination of crotonaldehyde 16 was carried out which provided intermediate 15 in 83\% yield. Intermediate 15 was then applied in a copper-catalysed Grignard addition to epoxide 14 which, upon separation via silica gel column chromatography, provided diastereomers 18 and 21 in an overall yield of 69\% [50]. 18 was subjected to our developed $\mathrm{ZrCl}_{4}$-catalysed one-pot deprotection/cyclisation technique to afford diastereomeric acetals 19 and 20 in a yield of $92 \%$. Conversion to the desired $\delta$-lactone 21 was achieved using the Lewis acid $\mathrm{BF}_{3} \cdot \mathrm{OEt}_{2}$ and mCPBA with a yield of 52\% [51,52]. Hydrogenolysis of the benzyl ether was carried out using Pearlman's catalyst at 25 bar pressure to provide (4S, 6S)-4-methyl-malyngolide 7 in a yield of $94 \%$. Diastereomer 21 was subjected to a similar synthetic sequence to afford $(4 R, 6 S)$-4-methyl-malyngolide 8 with yields of 89,42 and $65 \%$ obtained for the cyclisation, oxidation and deprotection steps, respectively. 


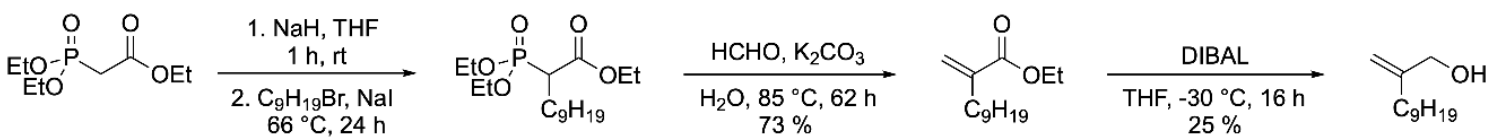

$51 \%$

10

Synthesis of Grignard Precursor 15

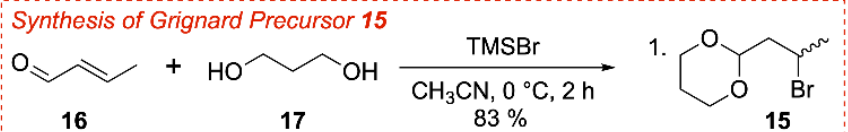

17

$83 \%$

15

Ti(O'Pr) 4 , (-)-DIPT

cumene hydroperoxide $\mathrm{CH}_{2} \mathrm{Cl}_{2},-25^{\circ} \mathrm{C}, 36 \mathrm{~h}$

$80 \%,>99 \%$ ee

$\mathrm{Mg}, \mathrm{Cul}(10 \mathrm{~mol} \%)$
THF, $-35^{\circ} \mathrm{C}, 2 \mathrm{~h}$

$69 \%$

2. Separation of

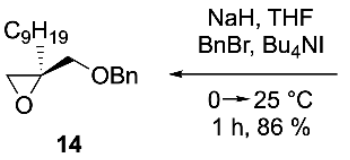
column chromatography

13

$\mathrm{ZrCl}_{4}(10 \mathrm{~mol} \%)$

$\mathrm{MeOH}, \mathrm{MW}, 100 \mathrm{~W}$

$50{ }^{\circ} \mathrm{C}, 6$ min

$92 \%$

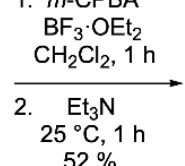

$52 \%$

$9 / 20$

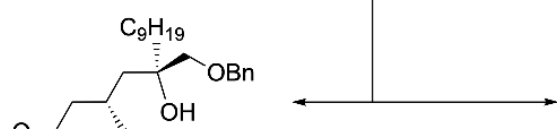

18

$(2 S, 4 S)$

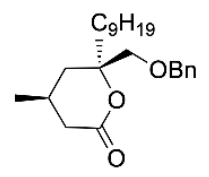

21

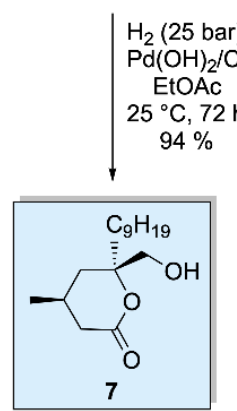

(4S, 6S)-4-methyl-malyngolide

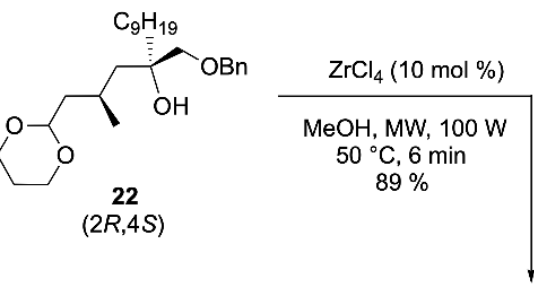

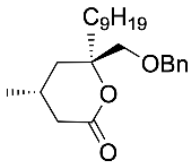

25

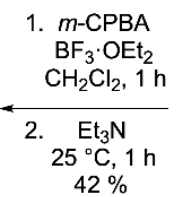

$42 \%$

$\mathrm{H}_{2}$ (25 bar)

$\mathrm{Pd}(\mathrm{OH})_{2} / \mathrm{C}$

EtOAc

$25^{\circ} \mathrm{C}, 72 \mathrm{~h}$

$65 \%$

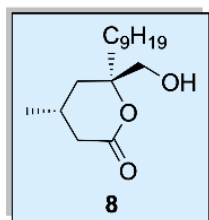

(4R, 6S)-4-methyl-malyngolide

Figure 3. Synthesis of malyngolide analogues 7 and 8.

With the synthesis complete, the new analogues 7 and 8 were tested for their biological activity (Table 2). The results indicate that the $n$-nonyl chain had a significant deleterious effect on the anti-MRSA action of the compounds. Analogues 7 and $\mathbf{8}$ displayed similar activity with their lowest MIC and MBC values of $50 \mu \mathrm{g} / \mathrm{mL}$. Further synthesis of modified analogues is currently underway in an effort to enhance the biological activity of this interesting class of compounds. 
Table 2. The MIC and MBC measurements for compounds 7 and 8.

\begin{tabular}{|c|c|c|c|c|c|c|c|c|}
\hline \multirow{2}{*}{ Compound } & \multicolumn{2}{|c|}{ E. coli 25922} & \multicolumn{2}{|c|}{ E. coli 4} & \multicolumn{2}{|c|}{$\begin{array}{c}\text { MRSA ATCC } \\
43300\end{array}$} & \multicolumn{2}{|c|}{ MRSA 06/04 } \\
\hline & $\mathrm{MIC}^{[\mathrm{a}]}$ & MBC & MIC & MBC & MIC & MBC & MIC & MBC \\
\hline 7 & $>100$ & $>100$ & $>100$ & $>100$ & 50 & 50 & 50 & 50 \\
\hline 8 & $>100$ & $>100$ & $>100$ & $>100$ & 50 & 100 & 50 & 50 \\
\hline
\end{tabular}

[a] MIC-minimum inhibitory concentration, $\mathrm{MBC}-$ minimum bactericidal concentration. Values are given in $\mu \mathrm{g} / \mathrm{mL}$. Bold-face values denote compounds that showed activity against the tested bacteria. The maximum concentration of compound tested in each case was $100 \mu \mathrm{g} / \mathrm{mL}$.

\section{Conclusions}

In summary, we have determined anti-methicillin-resistant Staphylococcus aureus activity (MIC of $12.5 \mu \mathrm{g} / \mathrm{mL}$ ) by a novel $\beta$-methyl analogue 5 of (+)-tanikolide $\mathbf{1}$. In an effort to improve upon this activity, two further analogues 7 and 8 bearing a shortened $n$-nonyl alkyl side chain were prepared in the present study using a $\mathrm{ZrCl}_{4}$-catalysed deprotection/cyclisation as the key step. When these were tested for activity against antimethicillin-resistant Staphylococcus aureus the MIC increased to $50 \mu \mathrm{g} / \mathrm{mL}$. It is hoped the results described above will lead to further improvements in this class of potentially potent anti-methicillin-resistant Staphylococcus aureus compounds.

\section{Materials and Methods-Chemistry}

Unless otherwise noted, reactions were performed with rigorous exclusion of air and moisture, under an inert atmosphere of nitrogen in flame-dried glassware with magnetic stirring using anhydrous solvents. $\mathrm{N}_{2}$-flushed stainless steel cannulas or plastic syringes were used to transfer air and moisture-sensitive reagents. All reagents were obtained from commercial sources and used without further purification unless otherwise stated. All anhydrous solvents were obtained from commercial sources and used as received with the following exceptions: diethyl ether $\left(\mathrm{Et}_{2} \mathrm{O}\right)$, dichloromethane $\left(\mathrm{CH}_{2} \mathrm{Cl}_{2}\right)$ and toluene $\left(\mathrm{PhCH}_{3}\right)$ were dried by passing through activated alumina columns. Powdered activated $4 \AA$ A molecular sieves were purchased from Sigma Aldrich and were stored in an oven at $120^{\circ} \mathrm{C}$. In vacuo refers to the evaporation of solvent under reduced pressure on a rotary evaporator. Thin-layer chromatography (TLC) was performed on aluminium plates precoated with silica gel F254. They were visualised with UV-light $(254 \mathrm{~nm})$ fluorescence quenching, or by charring with Hanessian's staining solution (cerium molybdate, $\mathrm{H}_{2} \mathrm{SO}_{4}$ in water), basic potassium permanganate staining solution (potassium permanganate, $\mathrm{K}_{2} \mathrm{CO}_{3}$ and $\mathrm{NaOH}$ in water), or an acidic vanillin staining solution (vanillin, $\mathrm{H}_{2} \mathrm{SO}_{4}$ in ethanol). Flash column chromatography was carried out using 40-63 $\mu \mathrm{m}, 230-400$ mesh silica gel.

${ }^{1} \mathrm{H}$ NMR spectra were recorded on a 300,400 or $500 \mathrm{MHz}$ spectrometer. ${ }^{13} \mathrm{C}$ NMR spectra were recorded on a 400 or $500 \mathrm{MHz}$ spectrometer at 101 or $126 \mathrm{MHz} .{ }^{19} \mathrm{~F}$ NMR spectra were recorded on a $400 \mathrm{MHz}$ spectrometer at $376 \mathrm{MHz}$. Chemical shifts $(\delta)$ are reported in parts per million (ppm) downfield from tetramethylsilane and for ${ }^{1} \mathrm{H}$ NMR are referenced to residual proton in the NMR solvent $\left(\mathrm{CDCl}_{3}=\delta 7.26 \mathrm{ppm}\right) .{ }^{13} \mathrm{C} \mathrm{NMR}$ are referenced to the residual solvent peak $\left(\mathrm{CDCl}_{3}=\delta 77.16 \mathrm{ppm}\right)$. All ${ }^{13} \mathrm{C}$ spectra are ${ }^{1} \mathrm{H}$ decoupled. NMR data are represented as follows: chemical shift ( $\delta \mathrm{ppm})$, integration, multiplicity $(\mathrm{s}=$ singlet, $\mathrm{d}=$ doublet $\mathrm{t}=$ triplet, $\mathrm{q}=$ quartet, $\mathrm{dd}=$ double doublet, $\mathrm{m}=$ multiplet, app. $\mathrm{d}=$ apparent doublet, app. t. $=$ apparent triplet), coupling constant $(J)$ in Hertz $(\mathrm{Hz})$. High resolution mass spectra [electrospray ionisation (ESI-TOF)] (HRMS) were measured on a micromass LCT orthogonal time-of-flight mass spectrometer with leucine enkephalin (Tyr-Gly-Phe-Leu) as an internal lock mass. Infrared spectra were recorded on a FT-IR spectrometer and are reported in terms of wavenumbers $\left(v_{\max }\right)$ with units of reciprocal centimetres $\left(\mathrm{cm}^{-1}\right)$. Microwave experiments were conducted in a CEM Discover S-class microwave reactor with controlled irradiation at $2.45 \mathrm{GHz}$ using standard microwave process Pyrex vials. Reaction time reflects time at the set reaction temperature maintained by cycling of irradiation (fixed hold times). Optical rotation $(\alpha)$ values were measured at room 
temperature and specific rotation $\left([\alpha]_{\mathrm{D}}^{20}\right)$ values are given in deg. $\mathrm{dm}^{-1} \cdot \mathrm{cm}^{3} \cdot \mathrm{g}^{-1}$. Melting points were determined in open capillary tubes. Supercritical fluid chromatography (SFC) was performed on a Waters UPC ${ }^{2}$ system using a Chiralpak IB column.

\subsection{Ethyl 2-(diethoxyphosphoryl)undecanoate (10)}

$\mathrm{NaH}(60 \%$ in mineral oil, $6.0 \mathrm{~g}, 150 \mathrm{mmol})$ was placed in a dry $500 \mathrm{~mL}$ two-necked room-bottom flask (RBF) containing a magnetic stirrer bar under an inert atmosphere, was washed with anhydrous hexanes $(2 \times 20 \mathrm{~mL})$ and dried under high vacuum. Dry THF $(250 \mathrm{~mL})$ was added to the reaction flask and triethylphosphonoacetate $9(19.8 \mathrm{~mL}$, $100 \mathrm{mmol})$ in dry THF $(30 \mathrm{~mL})$ was added dropwise over $20 \mathrm{~min}$ to the reaction mixture, with evolution of $\mathrm{H}_{2}$ gas. $\mathrm{NaI}(3.7 \mathrm{~g}, 25 \mathrm{mmol})$ was added to the reaction flask followed by dropwise addition of 1-bromononane $(9.6 \mathrm{~mL}, 50 \mathrm{mmol})$ and the reaction mixture was heated at reflux for $24 \mathrm{~h}$. The reaction mixture was quenched with $\mathrm{H}_{2} \mathrm{O}(100 \mathrm{~mL})$ and the aqueous layer was extracted with ether $(3 \times 100 \mathrm{~mL})$. The combined organic layers were washed with $\mathrm{H}_{2} \mathrm{O}(100 \mathrm{~mL})$ and brine $(100 \mathrm{~mL})$ and dried with anhydrous $\mathrm{Na}_{2} \mathrm{SO}_{4}$. The solvent was removed in vacuo and the crude product was purified by silica gel column chromatography (pentane/ether, 9:1 $\rightarrow 4: 1$ ) to yield 10 as a colourless oil $(8.93 \mathrm{~g}, 51 \%)$.

Spectroscopic analysis of 10: $R_{\mathrm{f}}=0.20$ (pentane/diethyl ether, 1:9); IR (neat): $v_{\max }=3477$, 2926, 2854, 1729, 1465, 1250, $1029 \mathrm{~cm}^{-1} ;{ }^{1} \mathrm{H}$ NMR $\left(400 \mathrm{MHz}, \mathrm{CDCl}_{3}\right): \delta 4.28-4.09(\mathrm{~m}, 6 \mathrm{H})$, $2.92(\mathrm{ddd}, J=22.5,11.1,3.7 \mathrm{~Hz}, 1 \mathrm{H}), 2.04-1.90(\mathrm{~m}, 1 \mathrm{H}), 1.90-1.77(\mathrm{~m}, 1 \mathrm{H}), 1.50-1.09(\mathrm{~m}$, $23 \mathrm{H}), 0.88(\mathrm{t}, J=6.9 \mathrm{~Hz}, 3 \mathrm{H}) \mathrm{ppm} ;{ }^{13} \mathrm{C} \mathrm{NMR}\left(126 \mathrm{MHz}, \mathrm{CDCl}_{3}\right): \delta 169.2(\mathrm{~d}, J=4.8 \mathrm{~Hz})$, $62.6(\mathrm{~d}, J=6.6 \mathrm{~Hz}), 62.5(\mathrm{~d}, J=6.6 \mathrm{~Hz}), 61.2,45.8(\mathrm{~d}, J=131.0 \mathrm{~Hz}), 31.8,29.4,29.2$ $(\mathrm{d}, J=4.6 \mathrm{~Hz}), 29.0,28.4,28.3,26.9(\mathrm{~d}, J=5.0 \mathrm{~Hz}), 22.6,16.3(\mathrm{~d}, J=4.0 \mathrm{~Hz}), 16.3(\mathrm{~d}$, $J=4.0 \mathrm{~Hz}), 14.1,14.0 \mathrm{ppm} ;{ }^{31} \mathrm{P}$ NMR $\left(162 \mathrm{MHz}, \mathrm{CDCl}_{3}\right) \delta 22.98 \mathrm{ppm}$; HRMS (ESI-TOF): calcd. for $\mathrm{C}_{17} \mathrm{H}_{35} \mathrm{O}_{5} \mathrm{PNa}[\mathrm{M}+\mathrm{Na}]^{+} 373.2120$; found 373.2108. (see Figure $\mathrm{S} 2$ for ${ }^{1} \mathrm{H}$ and ${ }^{13} \mathrm{C}$ NMR spectra).

\subsection{Ethyl 2-methyleneundecanoate (11)}

Phosphate ester 10 (8.93 g, $25.5 \mathrm{mmol})$ was placed in a $250 \mathrm{~mL}$ two-necked RBF containing a magnetic stirrer bar, followed by deionised water $(30 \mathrm{~mL}), \mathrm{K}_{2} \mathrm{CO}_{3}(14.1 \mathrm{~g}$, $101.9 \mathrm{mmol}$ ) and aqueous formaldehyde $(16.5 \mathrm{~mL}, 37 \%, 203.8 \mathrm{mmol})$. The reaction mixture was stirred at $85{ }^{\circ} \mathrm{C}$ for $18 \mathrm{~h}$. The reaction mixture was extracted with diethyl ether $(3 \times 100 \mathrm{~mL})$. The combined organic layers were washed with $\mathrm{H}_{2} \mathrm{O}(100 \mathrm{~mL})$ and brine $(100 \mathrm{~mL})$ and dried with anhydrous $\mathrm{Na}_{2} \mathrm{SO}_{4}$. Excess solvent was removed in vacuo and the crude product was purified by silica gel column chromatography (pentane/diethyl ether, 9:1) to yield $\mathbf{1 1}$ as a colourless oil (4.24 g, 73\%). (see Figure S3 for ${ }^{1} \mathrm{H}$ and ${ }^{13} \mathrm{C}$ NMR spectra).

Spectroscopic analysis of 11: $R_{\mathrm{f}}=0.70$ (pentane/diethyl ether, 9:1); IR (neat): $v_{\max }=2926$, 2856, 1720, 1179, $1147 \mathrm{~cm}^{-1} ;{ }^{1} \mathrm{H}$ NMR $\left(400 \mathrm{MHz}, \mathrm{CDCl}_{3}\right) \delta 6.12(\mathrm{~d}, J=1.5 \mathrm{~Hz}, 1 \mathrm{H}), 5.50$ $(\mathrm{d}, J=1.5 \mathrm{~Hz}, 1 \mathrm{H}), 4.20(\mathrm{q}, J=7.1 \mathrm{~Hz}, 2 \mathrm{H}), 2.29(\mathrm{t}, J=7.7 \mathrm{~Hz}, 2 \mathrm{H}), 1.50-1.41(\mathrm{~m}, 2 \mathrm{H})$, 1.37-1.19 (m, $15 \mathrm{H}), 0.88(\mathrm{t}, J=7.0 \mathrm{~Hz}, 3 \mathrm{H}) \mathrm{ppm} ;{ }^{13} \mathrm{C}$ NMR $\left(126 \mathrm{MHz}, \mathrm{CDCl}_{3}\right) \delta$ 167.4, 141.2, 124.0, 60.5, 31.9, 31.8, 29.5, 29.4, 29.3, 29.2, 28.4, 22.7, 14.2, 14.1 ppm; HRMS (ESI-TOF): calcd. for $\mathrm{C}_{14} \mathrm{H}_{26} \mathrm{O}_{2} \mathrm{Na}[\mathrm{M}+\mathrm{Na}]^{+} 249.1831$; found 249.1840 .

\subsection{2-Methyleneundecan-1-ol (12)}

Allylic ester 11 (4.24 g, $18.71 \mathrm{mmol})$ was placed in a dry $100 \mathrm{~mL}$ two-necked RBF containing a magnetic stirrer bar and dissolved in dry THF $(55 \mathrm{~mL})$, under an inert atmosphere. The reaction mixture was cooled to $-30{ }^{\circ} \mathrm{C}$ and DIBAL $(25 \mathrm{wt} . \%$ in toluene, $9.5 \mathrm{~mL}$, $41 \mathrm{mmol}$ ) was added dropwise over $40 \mathrm{~min}$ and the reaction mixture was stirred for $1 \mathrm{~h}$. The reaction mixture was quenched with diethyl ether $(5 \mathrm{~mL})$ and a saturated solution of Rochelle's salt (potassium sodium tartrate) $(50 \mathrm{~mL})$. The reaction mixture was stirred for $16 \mathrm{~h}$ at room temperature. The product was extracted with diethyl ether $(3 \times 100 \mathrm{~mL})$. The combined organic layers were washed with $\mathrm{H}_{2} \mathrm{O}(100 \mathrm{~mL})$ and brine $(100 \mathrm{~mL})$ and dried 
with anhydrous $\mathrm{Na}_{2} \mathrm{SO}_{4}$. Excess solvent was removed in vacuo and the crude product was purified by silica gel column chromatography (pentane/diethyl ether, 4:1) to yield $\mathbf{1 2}$ as a colourless oil $(0.856 \mathrm{~g}, 25 \%)$. (see Figure $\mathrm{S} 4$ for ${ }^{1} \mathrm{H}$ and ${ }^{13} \mathrm{C}$ NMR spectra).

Spectroscopic analysis of 12: $R_{\mathrm{f}}=0.19$ (pentane/diethyl ether, 4:1); IR (neat): $v_{\max }=3323$, 2926, 2856, 1653, 1465, $1027 \mathrm{~cm}^{-1}$; ${ }^{1} \mathrm{H}$ NMR $\left(400 \mathrm{MHz}, \mathrm{CDCl}_{3}\right) \delta 5.03-4.98(\mathrm{~m}, 1 \mathrm{H}), 4.88$ $4.83(\mathrm{~m}, 1 \mathrm{H}), 4.07(\mathrm{~s}, 2 \mathrm{H}), 2.05(\mathrm{t}, J=7.6 \mathrm{~Hz}, 2 \mathrm{H}), 1.50-1.37(\mathrm{~m}, 2 \mathrm{H}), 1.36-1.17(\mathrm{~m}, 12 \mathrm{H})$, $0.88(\mathrm{t}, J=6.9 \mathrm{~Hz}, 3 \mathrm{H}) \mathrm{ppm} ;{ }^{13} \mathrm{C} \mathrm{NMR}\left(126 \mathrm{MHz}, \mathrm{CDCl}_{3}\right) \delta 148.3,107.9,64.9,32.0,30.9,28.6$, 28.5, 28.4, 28.3, 26.8, 21.7, 13.1 ppm; HRMS (EI-TOF): calcd. for $\mathrm{C}_{12} \mathrm{H}_{24} \mathrm{O}[\mathrm{M}]^{+} 184.1828$; found 184.1827 .

\section{4. (R)-(2-Nonyloxiran-2-yl)methanol (13)}

Molecular sieves ( $4 \AA, 400 \mathrm{mg}$ ) and dry $\mathrm{CH}_{2} \mathrm{Cl}_{2}(11.5 \mathrm{~mL})$ were added to a dry $50 \mathrm{~mL}$ Schlenk tube containing a magnetic stirrer bar, followed by $\mathrm{Ti}\left(\mathrm{O}^{i} \mathrm{Pr}\right)_{4}(0.141 \mathrm{~mL}, 0.464 \mathrm{mmol})$ and (-)-diisopropyltartrate $(0.146 \mathrm{~mL}, 0.697 \mathrm{mmol})$, at $-35^{\circ} \mathrm{C}$ under an inert atmosphere. The reaction mixture was stirred for $30 \mathrm{~min}$. Allylic alcohol $12(0.856 \mathrm{~g}, 4.64 \mathrm{mmol})$ was added and the mixture was stirred for $30 \mathrm{~min}$. Cumene hydroperoxide $(1.37 \mathrm{~mL}, 9.29 \mathrm{mmol})$ was added over $20 \mathrm{~min}$. The reaction temperature was increased to $-25^{\circ} \mathrm{C}$ and the progress of the reaction was monitored by TLC until the consumption of the alcohol. Upon reaction completion at $18 \mathrm{~h}$, the reaction mixture was quenched with saturated sodium bicarbonate solution $(1 \mathrm{~mL})$ and ether $(5 \mathrm{~mL})$ and the resulting mixture was stirred for $2 \mathrm{~h}$ at room temperature. The reaction mixture was filtered through a pad of Celite ${ }^{\circledR}$ and concentrated in vacuo. The epoxide was purified by silica gel column chromatography (pentane/diethyl ether, 9:1 $\rightarrow 4: 1)$ to yield epoxide 13 as a colourless oil $(0.743 \mathrm{~g}, 80 \%,>99 \%$ ee). (The ee was calculated by SFC analysis of benzyl-protected epoxide 7 (Waters Acquity UPC ${ }^{2}$, Chiracel $\mathrm{IB}, \mathrm{scCO}_{2}$ /isopropanol $=95: 5$, flow rate $=2 \mathrm{~mL} \mathrm{~min}{ }^{-1}$ ). . (see Figure $\mathrm{S} 5$ for ${ }^{1} \mathrm{H}$ and ${ }^{13} \mathrm{C}$ NMR spectra).

Spectroscopic analysis of 13: $R_{\mathrm{f}}=0.22$ (pentane/diethyl ether, 3:2); SFC: $\mathrm{R}_{\mathrm{t}}(R)=1.543 \mathrm{~min}$ (major); $\mathrm{R}_{\mathrm{t}}(S)=2.215 \mathrm{~min}$ (minor); $[\alpha]_{\mathrm{D}}^{20}=+6.3\left(\mathrm{c}=1.0, \mathrm{CHCl}_{3}\right)$; IR (neat): $v_{\max }=3430$, 2926, 2856, 1466, $1047 \mathrm{~cm}^{-1} ;{ }^{1} \mathrm{H}$ NMR $\left(400 \mathrm{MHz}, \mathrm{CDCl}_{3}\right) \delta 3.75(\mathrm{dd}, J=12.3,4.4 \mathrm{~Hz}, 1 \mathrm{H})$, $3.61(\mathrm{dd}, J=12.3,8.6 \mathrm{~Hz}, 1 \mathrm{H}), 2.86(\mathrm{~d}, J=4.7 \mathrm{~Hz}, 1 \mathrm{H}), 2.64(\mathrm{~d}, J=4.7 \mathrm{~Hz}, 1 \mathrm{H}), 1.83-1.66$ $(\mathrm{m}, 2 \mathrm{H}), 1.48(\mathrm{dt}, J=14.0,7.5 \mathrm{~Hz}, 1 \mathrm{H}), 1.40-1.14(\mathrm{~m}, 14 \mathrm{H}), 0.85(\mathrm{t}, J=6.8 \mathrm{~Hz}, 3 \mathrm{H}) \mathrm{ppm}$; ${ }^{13} \mathrm{C}$ NMR $\left(101 \mathrm{MHz}, \mathrm{CDCl}_{3}\right) \delta 62.7,59.8,49.8,32.0,31.8,29.7,29.4,29.2,24.6,22.6,14.1 \mathrm{ppm}$; HRMS (ESI-TOF): calcd. for $\mathrm{C}_{12} \mathrm{H}_{24} \mathrm{O}_{2} \mathrm{Na}$ [M + Na] ${ }^{+} 223.1674$; found 223.1683.

\section{5. (S)-2-[Benzyloxy)methyl]-2-undecyloxirane (14)}

$\mathrm{NaH}(60 \%$ in mineral oil, $0.175 \mathrm{~g}, 4.379 \mathrm{mmol})$ was placed in a dry $100 \mathrm{~mL}$ twonecked RBF containing a magnetic stirrer bar under an inert nitrogen atmosphere, washed with anhydrous hexanes $(2 \times 5 \mathrm{~mL})$ and dried under high vacuum. Dry THF $(14.6 \mathrm{~mL})$ was added and the reaction vessel cooled to $0{ }^{\circ} \mathrm{C}$. Epoxide $13(0.731 \mathrm{~g}, 3.649 \mathrm{mmol})$ was dissolved in dry THF $(2 \mathrm{~mL})$ and added to the reaction mixture, which was stirred for $30 \mathrm{~min}$. Benzyl bromide $(0.46 \mathrm{~mL}, 3.83 \mathrm{mmol})$ was added dropwise followed by tetra- $n$ butylammonium iodide $(0.674 \mathrm{~g}, 1.825 \mathrm{mmol})$. The reaction mixture was stirred at $0{ }^{\circ} \mathrm{C}$ for $30 \mathrm{~min}$ and then at room temperature for $1 \mathrm{~h}$. The reaction mixture was quenched with $\mathrm{H}_{2} \mathrm{O}(10 \mathrm{~mL})$ and the aqueous layer extracted with diethyl ether $(3 \times 15 \mathrm{~mL})$. The organic layers were combined and washed with $\mathrm{H}_{2} \mathrm{O}(25 \mathrm{~mL})$ and brine $(25 \mathrm{~mL})$ and dried with anhydrous $\mathrm{Na}_{2} \mathrm{SO}_{4}$. The solvent was removed in vacuo and the crude product purified by silica gel column chromatography (pentane/diethyl ether, 9:1) to yield $\mathbf{1 4}$ as a colourless oil $(0.911 \mathrm{~g}, 86 \%)$. (see Figure $\mathrm{S} 6$ for ${ }^{1} \mathrm{H}$ and ${ }^{13} \mathrm{C}$ NMR spectra).

Spectroscopic analysis of 14: $\mathrm{R}_{\mathrm{f}}=0.60$ (pentane/diethyl ether, 4:1); $[\alpha]_{\mathrm{D}}{ }^{20}=-3.4(\mathrm{c}=1.0$, $\left.\mathrm{CHCl}_{3}\right)$; IR (neat): $v_{\max }=2926,2854,1454,1217,1095 \mathrm{~cm}^{-1} ;{ }^{1} \mathrm{H}$ NMR $\left(500 \mathrm{MHz}, \mathrm{CDCl}_{3}\right) \delta$ 7.39-7.26 (m, $5 \mathrm{H}), 4.59(\mathrm{~d}, J=12.0 \mathrm{~Hz}, 1 \mathrm{H}), 4.54(\mathrm{~d}, J=12.0 \mathrm{~Hz}, 1 \mathrm{H}), 3.61(\mathrm{~d}, J=11.1 \mathrm{~Hz}$, $1 \mathrm{H}), 3.47(\mathrm{~d}, J=11.1 \mathrm{~Hz}, 1 \mathrm{H}), 2.71(\mathrm{~d}, J=4.8 \mathrm{~Hz}, 1 \mathrm{H}), 2.64(\mathrm{~d}, J=4.8 \mathrm{~Hz}, 1 \mathrm{H}), 1.87-1.75$ 
(m, $1 \mathrm{H}), 1.61-1.50(\mathrm{~m}, 1 \mathrm{H}), 1.42-1.17(\mathrm{~m}, 14 \mathrm{H}), 0.88(\mathrm{t}, J=7.0 \mathrm{~Hz}, 3 \mathrm{H}) \mathrm{ppm} ;{ }^{13} \mathrm{C} \mathrm{NMR}$ $\left(101 \mathrm{MHz}, \mathrm{CDCl}_{3}\right) \delta 138.0,128.3,127.7,127.6,73.2,71.9,58.6,50.3,32.0,31.9,29.7,29.49,29.5$, 29.3, 24.6, 22.6, 14.1 ppm; HRMS (ESI-TOF): calcd. for $\mathrm{C}_{19} \mathrm{H}_{30} \mathrm{O}_{2} \mathrm{Na}[\mathrm{M}+\mathrm{Na}]^{+}$313.2144; found 313.2153 .

\subsection{2-(2-Bromopropyl)-1,3-dioxane (15)}

Anhydrous acetonitrile $(50 \mathrm{~mL})$ was added to a $250 \mathrm{~mL}$ RBF containing a magnetic stirrer bar under an inert nitrogen atmosphere and cooled to $0{ }^{\circ} \mathrm{C}$. Crotonaldehyde (16) $(4.1 \mathrm{~mL}, 50 \mathrm{mmol})$ was added followed by dropwise addition of TMSBr $(7.9 \mathrm{~mL}, 60 \mathrm{mmol})$ and the reaction mixture was stirred for $5 \mathrm{~min}$ prior to the dropwise addition of propan-1,3diol (17) $(4.3 \mathrm{~mL}, 60 \mathrm{mmol})$. The reaction mixture was stirred for $2.5 \mathrm{~h}$ at $0{ }^{\circ} \mathrm{C}$, the warmed to room temperature and quenched into a solution of pentane $(150 \mathrm{~mL})$ and $\mathrm{Na}_{2} \mathrm{CO}_{3}$ $(50 \mathrm{~mL}, 10 \% \mathrm{w} / \mathrm{v})$. The solution was stirred for $5 \mathrm{~min}$ and added to a separating funnel. Three layers were observed, the top layer containing pentane and the product, the middle layer containing acetonitrile and the product and the bottom aqueous layer. The aqueous layer was run-off and extracted with pentane $(10 \mathrm{~mL})$ and sodium thiosulfate $(50 \mathrm{~mL}$, $10 \% w / v)$. The organic fractions were combined, washed with water $(3 \times 60 \mathrm{~mL})$ and dried with anhydrous $\mathrm{Na}_{2} \mathrm{SO}_{4}$. Excess solvent was removed in vacuo and the remaining yellow solution was purified by high-vacuum distillation (bath temperature $105^{\circ} \mathrm{C}$, neck temperature $72{ }^{\circ} \mathrm{C}$ ) to yield 15 as a colourless oil $\left(8.66 \mathrm{~g}, 83 \%\right.$ ). (see Figure $\mathrm{S} 7$ for ${ }^{1} \mathrm{H}$ and ${ }^{13} \mathrm{C}$ NMR spectra).

Spectroscopic analysis of 15: $R_{\mathrm{f}}=0.38$ (pentane/diethyl ether, 9:1); IR (neat): $v_{\max }=2964$, 2856, 1379, $1140 \mathrm{~cm}^{-1} ;{ }^{1} \mathrm{H}$ NMR $\left(400 \mathrm{MHz}, \mathrm{CDCl}_{3}\right) \delta 4.70(\mathrm{dd}, J=7.1,3.4 \mathrm{~Hz}, 1 \mathrm{H}), 4.32-4.14$ (m, $1 \mathrm{H}), 4.13-3.98(\mathrm{~m}, 2 \mathrm{H}), 3.85-3.64(\mathrm{~m}, 2 \mathrm{H}), 2.22-1.86(\mathrm{~m}, 3 \mathrm{H}), 1.68(\mathrm{~d}, J=6.8 \mathrm{~Hz}, 3 \mathrm{H})$, 1.38-1.24 (m, $1 \mathrm{H}) \mathrm{ppm} ;{ }^{13} \mathrm{C}$ NMR $\left(101 \mathrm{MHz}, \mathrm{CDCl}_{3}\right) \delta 100.5,66.7,46.0,45.6,26.7,25.7 \mathrm{ppm}$; HRMS (EI-TOF): calcd. for $\mathrm{C}_{7} \mathrm{H}_{12} \mathrm{O}_{2}{ }^{79} \mathrm{Br}[\mathrm{M}-\mathrm{H}]^{+} 207.0021$ and $\mathrm{C}_{7} \mathrm{H}_{12} \mathrm{O}_{2}{ }^{81} \mathrm{Br}[\mathrm{M}-\mathrm{H}]^{+}$ 209.0000; found 207.0023 and 208.9995, respectively. All physical data was identical to those previously reported [5].

4.7. (2S,4S)-4-((Benzyloxy)methyl)-1-(1,3-dioxan-2-yl)-2-methyltridecan-4-ol ((2S,4S)-18) \& (2R,4S)-4-((benzyloxy)methyl)-1-(1,3-dioxan-2-yl)-2-methyltridecan-4-ol ((2R,4S)-22)

The Grignard reagent was prepared by addition of bromide $15(1.941 \mathrm{~g}, 9.285 \mathrm{mmol})$ to a dry $25 \mathrm{~mL}$ two-necked RBF containing a magnetic stirrer bar, magnesium turnings $(0.226 \mathrm{mg}, 9.285 \mathrm{mmol})$ and a crystal of $\mathrm{I}_{2}$ in anhydrous THF $(9 \mathrm{~mL})$ under an inert nitrogen atmosphere followed by heating to reflux for $1.5 \mathrm{~h}$ min. The solution was cooled to room temperature then transferred by cannula to a dry $25 \mathrm{~mL}$ two-necked $\mathrm{RBF}$ containing copper (I) iodide $(0.059 \mathrm{~g}, 0.310 \mathrm{mmol})$ at $-45^{\circ} \mathrm{C}$ and stirred for $30 \mathrm{~min}$. Benzyl epoxide $14(0.899 \mathrm{~g}$, $3.095 \mathrm{mmol})$ in anhydrous THF $(3 \mathrm{~mL})$ was added dropwise over $20 \mathrm{~min}$ and stirring was continued for a further $2 \mathrm{~h}$ at $-45^{\circ} \mathrm{C}$. The reaction was quenched by the addition of solid $\mathrm{NH}_{4} \mathrm{Cl}(0.90 \mathrm{~g})$ and saturated $\mathrm{NH}_{4} \mathrm{Cl}$ solution $(5 \mathrm{~mL})$ and the solution was stirred at room temperature for $10 \mathrm{~min}$. The solution was extracted with ethyl acetate $(6 \times 30 \mathrm{~mL})$ and the combined organic layers were washed with water $(50 \mathrm{~mL})$ and brine $(50 \mathrm{~mL})$ and dried with anhydrous $\mathrm{Na}_{2} \mathrm{SO}_{4}$. The solvent was removed in vacuo and the crude product purified by silica gel column chromatography (pentane/dichloromethane/ether, 5.5:3:1.5, repeated three times) to yield $(2 S, 4 S)-\mathbf{1 8}$ as a colourless oil $(0.397 \mathrm{~g}, 30 \%),(2 R, 4 S)-\mathbf{2 2}$ as a colourless oil $(0.424 \mathrm{~g}, 33 \%)$ and a mixture $(0.072 \mathrm{~g}, 6 \%)$. (see Figure $\mathrm{S} 8$ for ${ }^{1} \mathrm{H}$ and ${ }^{13} \mathrm{C}$ NMR spectra of compound 8 and Figure $S 9$ for ${ }^{1} \mathrm{H}$ and ${ }^{13} \mathrm{C}$ NMR spectra of compound 22).

Spectroscopic analysis of $(2 S, 4 S)-\mathbf{1 8}: \mathrm{R}_{\mathrm{f}}=0.38$ (pentane/diethyl ether, $\left.1: 1\right) ;[\alpha]_{\mathrm{D}}{ }^{20}=-3.5$ ( $\mathrm{c}=0.7, \mathrm{CHCl}_{3}$ ); IR (neat): $\gamma_{\max }=3446,2962,2852,1454,1261,1088 \mathrm{~cm}^{-1} ;{ }^{1} \mathrm{H}$ NMR $\left(500 \mathrm{MHz}, \mathrm{CDCl}_{3}\right) \delta 7.38-7.24(\mathrm{~m}, 5 \mathrm{H}), 4.62-4.47(\mathrm{~m}, 3 \mathrm{H}), 4.08(\mathrm{dd}, J=12.1,4.9 \mathrm{~Hz}, 2 \mathrm{H})$, $3.72(\mathrm{td}, J=12.1,2.4 \mathrm{~Hz}, 2 \mathrm{H}), 3.34(\mathrm{~d}, J=8.9 \mathrm{~Hz}, 1 \mathrm{H}), 3.30(\mathrm{~d}, J=8.9 \mathrm{~Hz}, 1 \mathrm{H}), 2.45(\mathrm{~s}, 1 \mathrm{H})$, 2.13-1.99 (m, $1 \mathrm{H}), 1.87(\mathrm{dtd}, J=13.5,6.8,4.6 \mathrm{~Hz}, 1 \mathrm{H}), 1.68-1.59(\mathrm{~m}, 1 \mathrm{H}), 1.58-1.42(\mathrm{~m}$, $5 \mathrm{H}), 1.38(\mathrm{dd}, J=14.5,7.1 \mathrm{~Hz}, 1 \mathrm{H}), 1.34-1.16(\mathrm{~m}, 14 \mathrm{H}), 1.00(\mathrm{~d}, J=6.7 \mathrm{~Hz}, 3 \mathrm{H}), 0.88(\mathrm{t}$, 
$J=7.0 \mathrm{~Hz}, 3 \mathrm{H}) \mathrm{ppm} ;{ }^{13} \mathrm{C} \mathrm{NMR}\left(101 \mathrm{MHz}, \mathrm{CDCl}_{3}\right) \delta 138.3,128.3,127.6,127.5,101.3,75.6$, $74.3,73.3,66.8,66.8,43.7,43.2,37.5,31.9,30.3,29.6,29.6,29.3,25.8,24.0,23.6,22.7,22.6$, 14.1 ppm; HRMS (ESI-TOF): calcd. for $\mathrm{C}_{26} \mathrm{H}_{44} \mathrm{O}_{4}[\mathrm{M}+\mathrm{Na}]^{+} 443.3137$; found 443.3120 .

Spectroscopic analysis of $(2 R, 4 S)-22: \mathrm{R}_{\mathrm{f}}=0.32$ (pentane/diethyl ether, $\left.1: 1\right) ;[\alpha]_{\mathrm{D}}{ }^{20}=+3.2$ (c = 0.55, $\mathrm{CHCl}_{3}$ ); IR (neat): $v_{\max }=3452,2960,2852,1454,1263,1109 \mathrm{~cm}^{-1} ;{ }^{1} \mathrm{H}$ NMR $\left(500 \mathrm{MHz}, \mathrm{CDCl}_{3}\right) \delta 7.37-7.22(\mathrm{~m}, 5 \mathrm{H}), 4.60-4.44(\mathrm{~m}, 3 \mathrm{H}), 4.06(\mathrm{dd}, J=12.1,4.2 \mathrm{~Hz}, 2 \mathrm{H})$, $3.71(\mathrm{td}, J=12.1,2.4 \mathrm{~Hz}, 2 \mathrm{H}), 3.32(\mathrm{~d}, J=8.9 \mathrm{~Hz}, 1 \mathrm{H}), 3.28(\mathrm{~d}, J=8.9 \mathrm{~Hz}, 1 \mathrm{H}), 2.47(\mathrm{~s}$, $1 \mathrm{H}), 2.13-1.95(\mathrm{~m}, 1 \mathrm{H}), 1.85(\mathrm{dt}, J=13.4,6.7,4.6 \mathrm{~Hz}, 1 \mathrm{H}), 1.69-1.56(\mathrm{~m}, 1 \mathrm{H}), 1.55-1.40(\mathrm{~m}$, $5 \mathrm{H}), 1.36(\mathrm{dd}, J=14.5,7.0 \mathrm{~Hz}, 1 \mathrm{H}), 1.33-1.14(\mathrm{~m}, 14 \mathrm{H}), 0.98(\mathrm{~d}, J=6.7 \mathrm{~Hz}, 3 \mathrm{H}), 0.87(\mathrm{t}$, $J=6.8 \mathrm{~Hz}, 3 \mathrm{H}) \mathrm{ppm} ;{ }^{13} \mathrm{C} \mathrm{NMR}\left(101 \mathrm{MHz}, \mathrm{CDCl}_{3}\right) \delta 138.3,128.3,127.5,127.5,101.4,75.8$, 74.3, 73.3, 66.8, 66.8, 43.5, 43.4, 37.4, 31.8, 30.3, 29.6, 29.5, 29.3, 25.8, 24.0, 23.6, 22.7, 22.6, 14.1 ppm; HRMS (ESI-TOF): calcd. for $\mathrm{C}_{26} \mathrm{H}_{44} \mathrm{O}_{4}[\mathrm{M}+\mathrm{Na}]^{+} 443.3137$; found 443.3125 .

\section{8. (2S,4R)-2-((Benzyloxy)methyl)-6-methoxy-4-methyl-2-nonyltetrahydro-2H-pyran (23/24)}

Dioxane (2R,4S)-22 (0.230 g, $0.547 \mathrm{mmol})$ and $\mathrm{ZrCl}_{4}(0.013 \mathrm{~g}, 0.055 \mathrm{mmol})$ was dissolved in anhydrous methanol $(0.6 \mathrm{~mL})$ in a $10 \mathrm{~mL}$ microwave vial containing a stirrer bar and stirred under microwave irradiation at $50{ }^{\circ} \mathrm{C}$ at $100 \mathrm{~W}$ for $6 \mathrm{~min}$. The crude product was purified directly by silica gel column chromatography (pentane/diethyl ether, 9:1) to yield 23 and 24 as an inseparable mixture of colourless oils (0.184 g, 89\%). (see Figure S10 for ${ }^{1} \mathrm{H}$ and ${ }^{13} \mathrm{C}$ NMR spectra of compounds $23 / 24$ ).

Spectroscopic analysis carried out on pure mixture 23/24: $R_{\mathrm{f}}=0.28$ (pentane/diethyl ether, 9:1); $[\alpha]_{\mathrm{D}}^{20}=-31.9\left(\mathrm{c}=1.0, \mathrm{CHCl}_{3}\right) ; \mathrm{IR}$ (neat): $v_{\max }=2929,2854,1454,1101,1053 \mathrm{~cm}^{-1}$; ${ }^{1} \mathrm{H}$ NMR $\left(400 \mathrm{MHz}, \mathrm{CDCl}_{3}\right) \delta 7.37-7.21(\mathrm{~m}, 5 \mathrm{H}), 4.79(\mathrm{~d}, J=3.5 \mathrm{~Hz}, 1 \mathrm{H}), 4.61-4.52(\mathrm{~m}$, $3 \mathrm{H}), 4.49(\mathrm{dd}, J=9.8,2.3 \mathrm{~Hz}, 1 \mathrm{H}), 3.48-3.37(\mathrm{~m}, 4 \mathrm{H}), 3.31-3.22(\mathrm{~m}, 1 \mathrm{H}), 2.12-1.94(\mathrm{~m}, 1 \mathrm{H})$, 1.93-1.40 (m, $5 \mathrm{H}), 1.37-0.80(\mathrm{~m}, 25 \mathrm{H}) \mathrm{ppm} ;{ }^{13} \mathrm{C}$ NMR $\left(101 \mathrm{MHz}, \mathrm{CDCl}_{3}\right) \delta 138.8,138.8$, 128.4, 128.4, 127.8, 127.6, 127.6, 99.9, 97.9, 77.4, 77.3, 76.5, 76.0, 73.6, 56.0, 55.7, 40.5, 39.9, 39.1, 39.0, 35.3, 32.1, 30.9, 30.6, 30.4, 29.8, 29.8, 29.5, 25.2, 24.6, 22.8, 22.6, 22.3, 19.9, 14.3 ppm; HRMS (ESI-TOF): calcd. for $\mathrm{C}_{24} \mathrm{H}_{40} \mathrm{O}_{3} \mathrm{Na}[\mathrm{M}+\mathrm{Na}]^{+}$399.2875; found 399.2865.

\section{9. (2S,4S)-2-((Benzyloxy)methyl)-6-methoxy-4-methyl-2-nonyltetrahydro-2H-pyran (19/20)}

Dioxane $(2 S, 4 S)-18(0.291 \mathrm{~g}, 0.691 \mathrm{mmol})$ was subjected to the same procedure as 22. The crude product was purified directly by silica gel column chromatography (pentane/diethyl ether, 9:1) to yield $\mathbf{1 9}$ and $\mathbf{2 0}$ as an inseparable mixture of colourless oils $(0.240 \mathrm{~g}, 92 \%)$. (see Figure S11 for ${ }^{1} \mathrm{H}$ and ${ }^{13} \mathrm{C}$ NMR spectra of compounds 19/20).

Spectroscopic analysis carried out on pure mixture 19/20: $R_{\mathrm{f}}=0.75$ (pentane/ethyl acetate, 9:1); $[\alpha]_{\mathrm{D}}^{20}=-18.3\left(\mathrm{c}=0.5, \mathrm{CHCl}_{3}\right) ; \mathrm{IR}$ (neat): $v_{\max }=2923,2853,1454,1376 \mathrm{~cm}^{-1} ;{ }^{1} \mathrm{H}$ $\operatorname{NMR}\left(400 \mathrm{MHz}, \mathrm{CDCl}_{3}\right) \delta 7.38-7.27(\mathrm{~m}, 5 \mathrm{H}), 4.73(\mathrm{~d}, \mathrm{~J}=3.4 \mathrm{~Hz}, 1 \mathrm{H}), 4.58-4.51(\mathrm{~m}, 3 \mathrm{H})$, $3.69(\mathrm{~d}, \mathrm{~J}=9.0 \mathrm{~Hz}, 1 \mathrm{H}), 3.56-3.40(\mathrm{~m}, 3 \mathrm{H}), 3.36(\mathrm{~s}, 3 \mathrm{H}), 1.93(\mathrm{~m}, 1 \mathrm{H}), 1.83-1.47(\mathrm{~m}, 5 \mathrm{H})$, 1.39-1.14 (m, $19 \mathrm{H}), 1.04-0.81(\mathrm{~m}, 9 \mathrm{H}) \mathrm{ppm} ;{ }^{13} \mathrm{C}$ NMR $\left(101 \mathrm{MHz}, \mathrm{CDCl}_{3}\right) \delta 138.9,138.7$, 128.5, 128.4, 127.7, 127.6, 127.6, 127.5, 99.7, 98.5, 77.0, 76.3, 73.5, 73.3, 72.7, 70.4, 55.9, 55.5, $40.1,39.9,39.6,39.4,39.4,38.8,32.1,30.4,30.4,29.9,29.8,29.8,29.8,29.5,25.5,23.0,23.0,22.9$, 22.5, 22.4, 20.3, 14.3 ppm; HRMS (ESI-TOF): calcd. for $\mathrm{C}_{24} \mathrm{H}_{40} \mathrm{O}_{3} \mathrm{Na}[\mathrm{M}+\mathrm{Na}]^{+} 399.2875$; found 399.2864 .

\subsection{0. (4R,6S)-6-((Benzyloxy)methyl)-4-methyl-6-nonyltetrahydro-2H-pyran-2-one (25)}

Acetals 23/24 $(0.164 \mathrm{~g}, 0.436 \mathrm{mmol})$ were dissolved in $\mathrm{CH}_{2} \mathrm{Cl}_{2}(13 \mathrm{~mL})$ in a dry $50 \mathrm{~mL}$ Schlenk tube containing a magnetic stirrer bar and cooled to $0{ }^{\circ} \mathrm{C}$. $m$-CPBA $(0.113 \mathrm{~g},<77 \%$, $0.653 \mathrm{mmol})$ was added followed by $\mathrm{BF}_{3} \cdot \mathrm{OEt}_{2}(0.070 \mathrm{~mL}, 0.566 \mathrm{mmol})$ and the reaction mixture was stirred at room temperature for $30 \mathrm{~min}$. The reaction mixture was cooled back to $0{ }^{\circ} \mathrm{C}$, quenched slowly with $\mathrm{Et}_{3} \mathrm{~N}(0.30 \mathrm{~mL}, 2.18 \mathrm{mmol})$ and stirred for $30 \mathrm{~min}$. Excess solvent removed in vacuo. The crude product residue was purified by silica gel column 
chromatography (pentane/diethyl ether, 4:1) to yield 25 as a colourless oil (0.066 g, 42\%). (see Figure $\mathrm{S} 12$ for ${ }^{1} \mathrm{H}$ and ${ }^{13} \mathrm{C}$ NMR spectra).

Spectroscopic analysis of 25: $R_{\mathrm{f}}=0.36$ (pentane/diethyl ether, 3:2); $[\alpha]_{\mathrm{D}}{ }^{20}=-7.0$ (c=0.9, $\left.\mathrm{CHCl}_{3}\right)$; IR (neat): $v_{\max }=2929,2856,1720,1454,1215,1099 \mathrm{~cm}^{-1} ;{ }^{1} \mathrm{H} \mathrm{NMR}(400 \mathrm{MHz}$, $\left.\mathrm{CDCl}_{3}\right) \delta 7.44-7.22(\mathrm{~m}, 5 \mathrm{H}), 4.62(\mathrm{~d}, J=12.1 \mathrm{~Hz}, 1 \mathrm{H}), 4.54(\mathrm{~d}, J=12.1 \mathrm{~Hz}, 1 \mathrm{H}), 3.46(\mathrm{~s}$, $2 \mathrm{H}), 2.62-2.51(\mathrm{~m}, 1 \mathrm{H}), 2.16-1.97(\mathrm{~m}, 2 \mathrm{H}), 1.81(\mathrm{dd}, J=13.6,3.5 \mathrm{~Hz}, 1 \mathrm{H}), 1.74-1.54(\mathrm{~m}$, $3 \mathrm{H}), 1.48-1.17(\mathrm{~m}, 14 \mathrm{H}), 1.04(\mathrm{~d}, J=6.0 \mathrm{~Hz}, 3 \mathrm{H}), 0.90(\mathrm{t}, J=6.7 \mathrm{~Hz}, 3 \mathrm{H}) \mathrm{ppm} ;{ }^{13} \mathrm{C} \mathrm{NMR}$ $\left(101 \mathrm{MHz}, \mathrm{CDCl}_{3}\right) \delta 171.8,138.0,128.4,127.6,127.6,85.1,75.2,73.6,38.2,37.6,36.3,31.8,30.0$, 29.5, 29.4, 29.2, 24.0, 23.3, 22.6, 21.2, 14.1 ppm; HRMS (ESI-TOF): calcd. for $\mathrm{C}_{23} \mathrm{H}_{36} \mathrm{O}_{3} \mathrm{Na}$ $[\mathrm{M}+\mathrm{Na}]^{+} 383.2562 ; 383.2574$.

\subsection{1. (4.S,6S)-6-((Benzyloxy)methyl)-4-methyl-6-nonyltetrahydro-2H-pyran-2-one (21)}

Acetals $19 / 20(0.212 \mathrm{~g}, 0.563 \mathrm{mmol})$ were subjected to the same procedure as $\mathbf{2 3} / \mathbf{2 4}$. The crude product residue was purified by silica gel column chromatography (pentane/diethyl ether, 4:1) to yield 21 as a colourless oil (0.106 g, 52\%). (see Figure S13 for ${ }^{1} \mathrm{H}$ and ${ }^{13} \mathrm{C}$ NMR spectra).

Spectroscopic analysis of 21: $\mathrm{R}_{\mathrm{f}}=0.29$ (pentane/ethyl acetate, 95:5); $[\alpha]_{\mathrm{D}}{ }^{20}=+27.75$ (c = 0.55, $\left.\mathrm{CHCl}_{3}\right)$; IR (neat): $v_{\max }=3017,2963,2855,1717,1455 \mathrm{~cm}^{-1} ;{ }^{1} \mathrm{H}$ NMR $(400 \mathrm{MHz}$, $\left.\mathrm{CDCl}_{3}\right) \delta$ 7.38-7.26 (m, $\left.5 \mathrm{H}\right), 4.56-4.44(\mathrm{~m}, 2 \mathrm{H}), 3.44(\mathrm{~s}, 2 \mathrm{H}), 2.61-2.53(\mathrm{~m}, 1 \mathrm{H}), 2.22-2.08$ $(\mathrm{m}, 1 \mathrm{H}), 2.05-1.97(\mathrm{~m}, 1 \mathrm{H}), 1.88(\mathrm{dd}, \mathrm{J}=17.5,12.1 \mathrm{~Hz}, 1 \mathrm{H}), 1.72-1.53(\mathrm{~m}, 2 \mathrm{H}), 1.45-1.18$ $(\mathrm{m}, 15 \mathrm{H}), 0.96(\mathrm{~d}, \mathrm{~J}=6.4 \mathrm{~Hz}, 3 \mathrm{H}), 0.88(\mathrm{t}, \mathrm{J}=6.9 \mathrm{~Hz}, 3 \mathrm{H}) \mathrm{ppm} ;{ }^{13} \mathrm{C} \mathrm{NMR}\left(101 \mathrm{MHz}, \mathrm{CDCl}_{3}\right)$ $\delta 171.7,137.9,128.6,127.9,127.8,84.7,74.1,73.7,39.3,38.4,37.2,32.0,30.0,29.7,29.5,23.9$, 22.8, 22.8, 21.7, 14.3 ppm; HRMS (ESI-TOF): calcd. for $\mathrm{C}_{23} \mathrm{H}_{36} \mathrm{O}_{3} \mathrm{Na}[\mathrm{M}+\mathrm{Na}]^{+}$383.2562; found 383.2558 .

\subsection{2. (4. R,6S)-4-Methylmalyngolide (8)}

In a $10 \mathrm{~mL}$ conical flask containing a magnetic stirrer bar, protected lactone $25(0.045 \mathrm{~g}$, $0.125 \mathrm{mmol})$ was dissolved in ethyl acetate $(2 \mathrm{~mL})$ and $\mathrm{Pd}(\mathrm{OH})_{2} / \mathrm{C}(20 \mathrm{wt} . \%)(0.0018 \mathrm{~g}$, $0.0125 \mathrm{mmol}$ ) was added. The reaction vessel was placed in a Parr reactor under $25 \mathrm{bar} \mathrm{H}_{2}$ pressure for $72 \mathrm{~h}$. The reaction was monitored by TLC (pentane/diethyl ether, 1:1). Upon reaction completion, the crude product was run through a small silica gel column (ethyl acetate) to yield $(4 R, 6 S)$-4-methylmalyngolide 8 as a colourless oil $(0.022 \mathrm{mg}, 65 \%)$. (see Figure S14 for ${ }^{1} \mathrm{H}$ and ${ }^{13} \mathrm{C}$ NMR spectra).

Spectroscopic analysis of 8: $\mathrm{R}_{\mathrm{f}}=0.08$ (pentane/diethyl ether, 1:1); $[\alpha]_{\mathrm{D}}{ }^{20}=-14.8$ (c = 0.7, $\mathrm{CHCl}_{3}$ ); IR (neat): $v_{\max }=3423,2924,2854,1722,1458,1377,1246,1088 \mathrm{~cm}^{-1} ;{ }^{1} \mathrm{H}$ NMR $\left(400 \mathrm{MHz}, \mathrm{CDCl}_{3}\right) \delta 3.68(\mathrm{~d}, \mathrm{~J}=12.0 \mathrm{~Hz}, 1 \mathrm{H}), 3.50-3.41(\mathrm{~m}, 1 \mathrm{H}), 2.60(\mathrm{ddd}, \mathrm{J}=17.2,4.4$, $2.2 \mathrm{~Hz}, 1 \mathrm{H}), 2.16-2.03(\mathrm{~m}, 1 \mathrm{H}), 1.97(\mathrm{dd}, \mathrm{J}=17.2,12.0 \mathrm{~Hz}, 1 \mathrm{H}), 1.79-1.67(\mathrm{~m}, 2 \mathrm{H}), 1.64-1.51$ $(\mathrm{m}, 2 \mathrm{H}), 1.42(\mathrm{~s}, 1 \mathrm{H}), 1.37-1.19(\mathrm{~m}, 14 \mathrm{H}), 1.03(\mathrm{~d}, \mathrm{~J}=6.3 \mathrm{~Hz}, 3 \mathrm{H}), 0.87(\mathrm{t}, \mathrm{J}=6.9 \mathrm{~Hz}, 3 \mathrm{H})$ ppm; ${ }^{13} \mathrm{C}$ NMR $\left(101 \mathrm{MHz}, \mathrm{CDCl}_{3}\right) \delta 171.6,86.6,67.7,38.1,36.5,34.6,31.8,30.0,29.5,29.4$, 29.2, 23.8, 23.5, 22.6, 21.4, 14.1 ppm; HRMS (ESI-TOF): calcd. for $\mathrm{C}_{16} \mathrm{H}_{30} \mathrm{O}_{3} \mathrm{Na}[\mathrm{M}+\mathrm{Na}]^{+}$ 293.2093; found 293.2088.

\subsection{3. (4S,6S)-4-Methylmalyngolide (7)}

Protected lactone $21(0.075 \mathrm{~g}, 0.208 \mathrm{mmol})$ was subjected to the same procedure as $\mathbf{2 5}$. Upon reaction completion, the crude product was run through a small silica gel column (ethyl acetate) to yield $(4 S, 6 S)-4$-methylmalyngolide 7 as a colourless oil $(0.053 \mathrm{mg}, 94 \%)$. (see Figure $\mathrm{S} 15$ for ${ }^{1} \mathrm{H}$ and ${ }^{13} \mathrm{C}$ NMR spectra).

Spectroscopic analysis of $7: R_{f}=0.10$ (pentane/diethyl ether, $\left.1: 1\right) ;[\alpha]_{D}{ }^{20}=+45.3(c=0.35$, $\mathrm{CHCl}_{3}$ ); IR (neat): $v_{\max }=3018,2928,1711,1215 \mathrm{~cm}^{-1} ;{ }^{1} \mathrm{H}$ NMR $\left(400 \mathrm{MHz}, \mathrm{CDCl}_{3}\right) \delta 3.64$ $(\mathrm{d}, \mathrm{J}=11.7 \mathrm{~Hz}, 1 \mathrm{H}), 3.58(\mathrm{~d}, \mathrm{~J}=11.7 \mathrm{~Hz}, 1 \mathrm{H}), 2.59(\mathrm{ddd}, \mathrm{J}=17.4,4.5,2.3 \mathrm{~Hz}, 1 \mathrm{H}), 2.29-2.17$ $(\mathrm{m}, 1 \mathrm{H}), 1.95-1.84(\mathrm{~m}, 2 \mathrm{H}), 1.69-1.57(\mathrm{~m}, 2 \mathrm{H}), 1.43-1.18(\mathrm{~m}, 16 \mathrm{H}), 0.99(\mathrm{~d}, \mathrm{~J}=6.3 \mathrm{~Hz}$, 
$3 \mathrm{H}), 0.87(\mathrm{t}, \mathrm{J}=6.9 \mathrm{~Hz}, 3 \mathrm{H}) \mathrm{ppm} ;{ }^{13} \mathrm{C} \mathrm{NMR}\left(101 \mathrm{MHz}, \mathrm{CDCl}_{3}\right) \delta 172.1,86.1,68.0,38.4$, $38.4,37.1,32.0,30.0,29.6,29.4,24.4,23.1,22.8,21.6,14.2$ ppm; HRMS (ESI-TOF): calcd. for $\mathrm{C}_{16} \mathrm{H}_{30} \mathrm{O}_{3} \mathrm{Na}[\mathrm{M}+\mathrm{Na}]^{+}$293.2093; found 293.2080.

\section{Materials and Methods-Biological Testing}

\subsection{Preparation of Compounds}

Samples were reconstituted into an appropriate volume of DMSO to achieve a final concentration of $10 \mathrm{mg} / \mathrm{mL}$.

\subsection{Antibacterial Activity Testing-Determination of Minimum Inhibitory Concentration (MIC) and Minimum Bactericidal Concentration (MBC)}

Samples of each of these chemical compounds were reconstituted into an appropriate volume of DMSO to achieve a final concentration of $10 \mathrm{mg} / \mathrm{mL}$. MIC values for these compounds was determined by two-fold broth microdilution in 96-well microtiter plates. Briefly, overnight cultures of Escherichia coli ATCC 25922, Escherichia coli 4, MRSA ATCC 43300 and MRSA 06/04 (see Table S1 for further information about the isolates) were diluted in sterilised PBS to approximately $10^{5} \mathrm{CFU} / \mathrm{mL}$. Aliquots of $5 \mu \mathrm{L}$ were then transferred to separate wells in a 96-well plate that contained $100 \mu \mathrm{L}$ of each compound at varying concentrations (ranging from 100-0.195 $\mu \mathrm{g} / \mathrm{mL}$ ) prepared from two-fold serial dilutions in Mueller-Hinton (MH) broth. Plates were incubated at $37^{\circ} \mathrm{C}$ for $18 \mathrm{~h}$ using an Omnilog ${ }^{\circledR}$ automated incubator (Biolog Inc.; 21124 Cabot Boulevard, Hayward, CA 94545, USA) and MIC values recorded.

Determination of the MBC values for all compounds tested above was performed in $\mathrm{MH}$ broth media. Again, $5 \mu \mathrm{L}$ were collected from the MICs 96-well plates (above) and re-inoculated into fresh sterile 96-well plates containing fresh $\mathrm{MH}$. Plates were incubated under the same conditions mentioned above. The assay was performed in triplicate for each compound. (see Table S1 for UCD Centre for Food Safety strains used for determination of antibacterial activity and Table S2 for Antibacterial activity of compounds tested - MIC and $\mathrm{MBC}$ results (triplicates)).

Supplementary Materials: The following are available online at https:/ / www.mdpi.com/article/10 .3390/ijms22126400/s1. Figure S1: SFC Chromatograms of Reference and Intermediate 14; Figure S2: ${ }^{1} \mathrm{H}$ NMR and ${ }^{13} \mathrm{C}$ NMR Spectra of Compound 10; Figure S3: ${ }^{1} \mathrm{H}$ NMR and ${ }^{13} \mathrm{C}$ NMR Spectra of Compound 11; Figure S4: ${ }^{1} \mathrm{H}$ NMR and ${ }^{13} \mathrm{C}$ NMR Spectra of Compound 12; Figure S5: ${ }^{1} \mathrm{H}$ NMR and ${ }^{13} \mathrm{C}$ NMR Spectra of Compound 13; Figure S6: ${ }^{1} \mathrm{H}$ NMR and ${ }^{13} \mathrm{C}$ NMR Spectra of Compound 14; Figure S7: ${ }^{1} \mathrm{H}$ NMR and ${ }^{13} \mathrm{C}$ NMR Spectra of Compound 15; Figure S8: ${ }^{1} \mathrm{H}$ NMR and ${ }^{13} \mathrm{C}$ NMR Spectra of Compound 18; Figure S9: ${ }^{1} \mathrm{H}$ NMR and ${ }^{13} \mathrm{C}$ NMR Spectra of Compound 22; Figure S10: ${ }^{1} \mathrm{H}$ NMR and ${ }^{13} \mathrm{C}$ NMR Spectra of Compounds 23/24; Figure S11: ${ }^{1} \mathrm{H}$ NMR and ${ }^{13} \mathrm{C}$ NMR Spectra of Compounds 19/20; Figure S12: ${ }^{1} \mathrm{H}$ NMR and ${ }^{13} \mathrm{C}$ NMR Spectra of Compound 25; Figure S13: ${ }^{1} \mathrm{H}$ NMR and ${ }^{13} \mathrm{C}$ NMR Spectra of Compound 21; Figure S14: ${ }^{1} \mathrm{H}$ NMR and ${ }^{13} \mathrm{C}$ NMR Spectra of Compound 8; Figure S15: ${ }^{1} \mathrm{H}$ NMR and ${ }^{13} \mathrm{C}$ NMR Spectra of Compound 7.

Author Contributions: Conceptualisation, P.J.G.; synthetic methodology, J.B., C.K. and R.D.; biological testing J.A. and M.M.; writing—original draft preparation, C.K.; writing-review and editing, P.J.G.; supervision, P.J.G. and S.F.; project administration, P.J.G.; funding acquisition, P.J.G. All authors have read and agreed to the published version of the manuscript.

Funding: J.B. is grateful for the award of an IRCSET/LEO Pharma Enterprise Partnership Scheme Postgraduate Research Scholarship (EPSPG/2012/350). This publication has emanated from research conducted with the financial support of the Synthesis and Solid State Pharmaceutical Centre (SSPC), funded by Science Foundation Ireland (SFI) under grant numbers $12 \backslash R C \backslash 2275$. C.K. is grateful for the award of a SSPC Ph.D. Scholarship. R.D. is grateful for the award of an Irish Research Council (IRC) EMBARK Initiative PhD Scholarship (RS/2010/2191).

Acknowledgments: Facilities were provided by the Centre for Synthesis and Chemical Biology (CSCB), funded by the Higher Education Authority's PRTLI. The authors wish to thank Yannick Ortin of the UCD NMR Centre in the School of Chemistry/CSCB for help with NMR spectroscopic studies. 
Conflicts of Interest: The authors declare no conflict of interest.

\section{References}

1. Singh, S.; Duffy, C.; Shah, S.T.A.; Guiry, P.J. $\mathrm{ZrCl}_{4}$ as an efficient catalyst for a novel one-pot protection/deprotection synthetic methodology. J. Org. Chem. 2008, 73, 6429-6432. [CrossRef]

2. Singh, S.; Guiry, P.J. A facile synthesis of both enantiomers of 6-acetoxy-5-hexadecanolide, a major component of mosquito oviposition attractant pheromones. Eur. J. Org. Chem. 2009, 1896-1901. [CrossRef]

3. Singh, S.; Guiry, P.J. Microwave-assisted synthesis of substituted tetrahydropyrans catalyzed by $\mathrm{ZrCl}_{4}$ and its application in the asymmetric synthesis of exo- and endo-brevicomin. J. Org. Chem. 2009, 74, 5758-5761. [CrossRef] [PubMed]

4. Singh, S.; Guiry, P.J. A short and efficient asymmetric synthesis of (-)-frontalin, (-)-exo-isobrevicomin and a volatile contributor of beer-aroma. Tetrahedron 2010, 66, 5701-5706. [CrossRef]

5. Doran, R.; Duggan, L.; Singh, S.; Duffy, C.D.; Guiry, P.J. Asymmetric synthesis of (+)-tanikolide and the $\beta$-methyl-substituted analogues of (+)-tanikolide and (-)-malyngolide. Eur. J. Org. Chem. 2011, 7097-7106. [CrossRef]

6. Singh, I.P.; Milligan, K.E.; Gerwick, W.H. Tanikolide, a toxic and antifungal lactone from the marine cyanobacterium Lyngbya majuscula. J. Nat. Prod. 1999, 62, 1333-1335. [CrossRef] [PubMed]

7. Brown, G.D.; Denning, D.W.; Gow, N.A.R.; Levitz, S.M.; Netea, M.G.; White, T.C. Hidden killers: Human fungal infections. Sci. Trans. Med. 2012, 4, 165rv13. [CrossRef] [PubMed]

8. Giri, S.; Kindo, A.J. A review of Candida species causing blood stream infection. Indian J. Med. Microbiol. 2012, 30, $270-278$. [CrossRef] [PubMed]

9. Rabes, A.; Zimmermann, S.; Reppe, K.; Lang, R.; Seeberger, P.H.; Suttopr, N.; Witzenrath, M.; Lepenies, B.; Opitz, B. The C-type lectin receptor mincle binds to streptococcus pneumoniae but plays a limited role in the anti-pneumococcal innate immune response. PLoS ONE 2015, 10, 0117022. [CrossRef]

10. Odds, F.C.; Brown, A.J.P.; Gow, N.A.R. Antifungal agents: Mechanisms of action. Trends Microbiol. 2003, 11, 272-279. [CrossRef]

11. Cardllina, J.H., II; Moore, R.E.; Arnold, E.V.; Clardy, J. Structure and absolute configuration of malyngolide, an antibiotic from the marine blue-green alga Lyngbya majuscula Gomont. J. Org. Chem. 1979, 44, 4039-4042. [CrossRef]

12. Tong, S.Y.C.; Davis, J.S.; Eichenberger, E.; Holland, T.L.; Fowler, V.G. Staphylococcus aureus infections: Epidemiology, pathophysiology, clinical manifestations, and management. Clin. Microbiol. Rev. 2015, 28, 603-661. [CrossRef]

13. Klevens, R.M.; Morrison, M.A.; Nadle, J.; Petit, S.; Gershman, K.; Ray, S.; Harrison, L.H.; Lynfield, R.; Dumyati, G.; Townes, J.H.; et al. Invasive methicillin-resistant Staphylococcus aureus infections in the United States. JAMA 2007, 298, 1763-1771. [CrossRef]

14. McDougal, L.K.; Carey, R.B.; Talan, D.A. Methicillin-resistant S. aureus infections among patients in the emergency department. N. Engl. J. Med. 2006, 355, 666-674. [CrossRef]

15. Deresinski, S. Methicillin-resistant Staphylococcus aureus: An evolutionary, epidemiologic, and therapeutic odyssey. Clin. Infect. Dis. 2005, 40, 562-573. [CrossRef] [PubMed]

16. Walters, M.; Lonsway, D.; Rasheed, K.; Albrecht, V.; McAllister, S.; Limbago, B.; Kallen, A. Investigation and Control of Vancomycin-Resistant Staphylococcus aureus: A Guide for Health Departments and Infection Control Personnel. Atlanta, GA, USA, 2015. Available online: http://www.cdc.gov/hai/pdfs/VRSA-Investigation-Guide-05_12_2015.pdf (accessed on 10 June 2021).

17. Gemmell, C.G. Susceptibility of a variety of clinical isolates to linezolid: A European inter-country comparison. J. Antimicrob. Chemother. 2001, 48, 47-52. [CrossRef] [PubMed]

18. Sakito, Y.; Tanaka, S.; Asami, M.; Mukaiyama, T. An asymmetric total synthesis of a new marine antiobiotic-Malyngolide. Chem. Lett. 1980, 1223-1226. [CrossRef]

19. Mukaiyama, T. Asymmetric synthesis based on chiral diamines having pyrrolidine ring. Tetrahedron 1981, 37, 4111-4119. [CrossRef]

20. Kogure, T.; Eliel, E.L. A convergent asymmetric synthesis of (-)-malyngolide and its three stereoisomers. J. Org. Chem. 1984, 49, 576-578. [CrossRef]

21. Guingant, A. An asymmetric synthesis of (R)-(+)-2-nonyl-2-(carbomethoxy) cyclopentanone, a known precursor of the antibiotic (-)-malyngolide. Tetrahedron Asymmetry 1991, 2, 415-418. [CrossRef]

22. Enders, D.; Knopp, M. Novel asymmetric syntheses of (-)-malyngolide and (+)-epi-malyngolide. Tetrahedron 1996, 52, 5805-5818. [CrossRef]

23. Maezaki, N.; Matsumori, Y.; Shogaki, T.; Soejima, M.; Tanaka, T.; Ohishi, H.; Iwata, C. Stereoselective synthesis of a chiral synthon, 2,2,5-trisubstituted tetrahydropyran, based on simultaneous 1,3- and 1,6-asymmetric induction via nucleophilic acetal cleavage reaction of the bicyclic acetal: A total synthesis of (-)-malyngolide. Chem. Commun. 1997, 1755-1756. [CrossRef]

24. Winter, E.; Hoppe, D. A new route to the asymmetric synthesis of (-)-malyngolide and (-)-epi-malyngolide using $N$-sulfonyl-1,3oxazolidines as chiral auxiliaries. Tetrahedron 1998, 54, 10329-10338. [CrossRef]

25. Maezaki, N.; Matsumori, Y.; Shogaki, T.; Soejima, M.; Ohishi, H.; Tanaka, T.; Iwata, C. Stereoselective synthesis of a 2,2,5trisubstituted tetrahydropyran chiron via 1,3- and 1,6-asymmetric induction: A total synthesis of (-)-malyngolide. Tetrahedron 1998, 54, 13087-13104. [CrossRef]

26. Suziki, T.; Ohmori, K.; Suzuki, K. Pseudo- $C_{3}$-symmetric tertiary alcohol building block via group-selective hydroalumination: A synthesis of (-)-malyngolide. Org. Lett. 2001, 3, 1741-1744. [CrossRef] [PubMed] 
27. Date, M.; Tamai, Y.; Hattori, T.; Takayama, H.; Kamikubo, Y.; Miyano, S. Efficient 1,8- and 1,9-asymmetric inductions in the Grignard reaction of $\delta$ - and $\varepsilon$-keto esters of 1,1'-binaphthalen-2-ols with an oligoether tether as the $2^{\prime}$-substituent: Application to the synthesis of (-)-malyngolide. J. Chem. Soc. Perkin Trans. 2001, 1, 645-653. [CrossRef]

28. Pougny, J.-R.; Rollin, P.; Sinay, P. A synthesis of the marine antibiotic (-)-malyngolide from D-glucose. Tetrahedron Lett. 1982, 23, 4929-4932. [CrossRef]

29. Ho, P.-T.; Wong, S. Branched-chain sugars in asymmetric synthesis. Total synthesis of marine antibiotic (-)-malyngolide. Can. J. Chem. 1985, 63, 2221-2224. [CrossRef]

30. Tokunaga, Y.; Nagano, H.; Shiota, M. Synthesis of (+)-malyngolide from (+)-tartaric acid. J. Chem. Soc. Perkin Trans. 1986, 1, 581-584. [CrossRef]

31. Trinh, M.-C.; Florent, J.-C.; Monneret, C. Total synthesis of (s)-(-) and (r)-(+)-frontalin and of (-)-malyngolide from the branchedchain sugar " $\alpha$ "-d-isosaccharino-lactone as chiral template. Tetrahedron 1988, 44, 6633-6644. [CrossRef]

32. Honda, T.; Imai, M.; Keino, K.; Tsubuki, M. An enantiocontrolled synthesis of (-)-malyngolide. J. Chem. Soc. Perkin Trans. 1990, 1, 2677-2680. [CrossRef]

33. Ichimoto, I.; Machiya, K.; Kirihata, M.; Ueda, H. Stereoselective Synthesis of Marine Antibiotic (-)-Malyngolide and Its Stereoisomers. Agric. Biol. Chem. 1990, 54, 657-662. [CrossRef]

34. Matsuo, K.; Hasuike, Y.; Kado, H. Synthesis of (-)-Malyngolide from D-Lactose. Chem. Pharm. Bull. 1990, 38, 2847-2849. [CrossRef]

35. Nagano, H.; Ohno, M.; Miyamae, Y. Diastereoselective addition of grignard reagents to 3,4-O-Isopropylidene-1-Otriphenylmethyl-L-glycero-2-tetrulose and 1-O-Benzoyl-3,4-O-isopropylidene-L-glycero-2-tetrulose. Bull. Chem. Soc. Jpn. 1992, 65, 2814-2820. [CrossRef]

36. Ohira, S.; Ida, T.; Moritani, M.; Hasegawa, T. Synthesis of (-)-malyngolide using reactions of alkylidenecarbenes. J. Chem. Soc. Perkin Trans. 1998, 1, 293-297. [CrossRef]

37. Carda, M.; Castillo, E.; Rodriguez, S.; Marco, J.A. A stereoselective synthesis of (+)-malyngolide via a ring-closing olefin metathesis. Tetrahedron Lett. 2000, 41,5511-5513. [CrossRef]

38. Noda, Y.; Kikuchi, M. A convenient synthesis of (+)-Malyngolide. Synth. Commun. 1985, 15, 1245-1252. [CrossRef]

39. Wan, Z.; Nelson, S.G. Optically active allenes from $\beta$-lactone templates: Asymmetric total synthesis of (-)-Malyngolide. J. Am. Chem. Soc. 2000, 122, 10370-10471. [CrossRef]

40. Asaoka, M.; Hayashibe, S.; Sonoda, S.; Takei, H. New route to (-)-frontalin and (-)-malyngolide via epoxyketone rearrangement. Tetrahedron 1991, 47, 6967-6974. [CrossRef]

41. Flörke, H.; Schaumann, E. Synthesis of (-)-Malyngolide. Liebigs Ann. 1996, 147-151. [CrossRef]

42. Konno, H.; Hiroya, K.; Ogasawara, K. A new tactic for diastereo- and enantiocontrolled synthesis of (-)-malyngolide via catalytic meso-asymmetrization. Tetrahedron Lett. 1997, 38, 6023-6026. [CrossRef]

43. Kanada, R.M.; Taniguchi, T.; Ogasawara, K. Asymmetric hydrogen transfer protocol for a synthesis of (+)-frontalin and (-)malyngolide. Tetrahedron Lett. 2000, 41, 3631-3635. [CrossRef]

44. Ghosh, A.K.; Shirai, M. Asymmetric hetero Diels-Alder route to quaternary carbon centers: Synthesis of (-)-malyngolide. Tetrahedron Lett. 2001, 42, 6231-6233. [CrossRef]

45. Miyamoto, H.; Iwamoto, M.; Nakada, M. A new asymmetric total synthesis of enantiopure (-)-Malyngolide. Heterocycles 2005, 66, 61-68. [CrossRef]

46. Trost, B.M.; Tang, W.; Schulte, J.L. Asymmetric synthesis of quaternary centers. Total synthesis of (-)-Malyngolide. Org. Lett. 2000, 2, 4013-4015. [CrossRef] [PubMed]

47. Sato, T.; Maeno, H.; Noro, T.; Fujisawa, T. Asymmetric synthesis of (-)-Malyngolide and (-)-frontalin by utilizing bakers' yeast reduction of (S)-Ethyl-2-cyclopentanonecarboxylthiolate. Chem. Lett. 1988, 17, 1739-1742. [CrossRef]

48. Suemune, H.; Harabe, T.; Xie, Z.-F.; Sakai, K. Enzymatic hydrolysis of 2,2-Bis(acetoxymethyl)cycloalkanones, and its application to formal synthesis of (-)-Maylngolide. Chem. Pharm. Bull. 1988, 36, 4337-4344. [CrossRef]

49. Srivastava, N.; Reddy, B.V.S. Biocatalytic Approach for the total synthesis of (-)-Malyngolide and Its C(5)-Epimer. Helv. Chim. Acta 2016, 99, 267-272. [CrossRef]

50. O'Sullivan, T.P.; Vallin, K.S.A.; Shah, S.T.A.; Fakhry, J.; Maderna, P.; Scannell, M.; Sampaio, A.L.F.; Perretti, M.; Godson, C.; Guiry, P.J. Aromatic lipoxin $\mathrm{A}_{4}$ and lipoxin $\mathrm{B}_{4}$ analogues display potent biological activities. J. Med. Chem. 2007, 50, 5894-5902. [CrossRef] [PubMed]

51. Grieco, P.A.; Oguri, T.; Yokoyama, Y. One-step conversion of protected lactols into lactones. Tetrahedron Lett. 1978, 19, 419-420. [CrossRef]

52. Wan, S.; Gunaydin, H.; Houk, K.N.; Floreancig, P.E. An experimental and computational approach to defining structure/reactivity relationships for intramolecular addition reactions to bicyclic epoxonium ions. J. Am. Chem. Soc. 2007, 129, 7915-7923. [CrossRef] [PubMed] 